\begin{tabular}{|l|l|l|l|l|}
\hline SHARE: SOCIAL WORK JURNAL & VOLUME: 6 & NOMOR: 2 & HALAMAN: $154-272$ & $\begin{array}{r}\text { ISSN:2339-0042 }(p) \\
\text { ISSN: } 2528-1577(e)\end{array}$ \\
\hline
\end{tabular}

\title{
LGBT DALAM PERSPEKTIF HAK ASASI MANUSIA
}

\author{
OLEH: \\ MEILANNY BUDIARTI SANTOSO 1 \\ ${ }^{1}$ Staf Pengajar Departemen Kesejahteraan Sosial - Universitas Padjadjaran \\ Email: meilannybudiarti13@gmail.com
}

\begin{abstract}
Abstrak
Resolusi tentang pengakuan atas hak-hak LGBT adalah resolusi PBB yang pertama yang secara spesifik mengangkat isu pelanggaran HAM berdasarkan orientasi seksual dan identitas gender. Resolusi tentang pengakuan atas hak-hak LGBT inilah yang dijadikan sebagai landasan tuntutan bagi kaum LGBT dalam menuntut hak-hak mereka dengan mengatasnamakan hak asasi manusia. Namun demikian, di Indonesia, tentunya berbicara mengenai penegakkan hak asasi manusia, khususnya yang diperjuangkan oleh komunitas LGBT, penegakkannya harus disesuaikan dengan aturan hukum dan nilai-nilai Pancasila sebagai dasar Negara dan landasan falsafah kehidupan berbangsa dan bernegara.
\end{abstract}

\begin{abstract}
The resolution of recognition for LGBT's rights is the first resolution of the U.N. that specifically raise the issue of human rights' violations which based on a sexual orientation and gender identity. This kind of resolution for LGBT's recognition that used as the basic of their demands for the LGBTs in claiming their rights in the name of human rights. However, in Indonesia, definitely when we are talking about the enforcement of human rights, especially that had been fought by the community of LGBTs, the enforcement itself must be adjusted to the rule of law and also values of Pancasila as a fundamental of the state and philosophy as well, in our nation and state.
\end{abstract}

Kata kunci: Hak Asasi Manusia, LGBT, Mental Health, kritik konsep HAM 


\section{Pendahuluan}

Menurut survey CIA pada tahun 2015 yang dilansir di topikmalaysia.com jumlah populasi LGBT di Indonesia adalah ke-5 terbesar di dunia setelah China, India, Eropa dan Amerika. Selain itu, beberapa lembaga survey independen dalam maupun luar negeri menyebutkan bahwa Indonesia memiliki 3\% penduduk LGBT, ini berarti dari 250 juta penduduk 7,5 jutanya adalah LBGT, atau lebih sederhananya dari 100 orang yang berkumpul di suatu tempat 3 diantaranya adalah LGBT.

Permasalahan LGBT di Indonesia banyak menimbulkan pertentangan pendapat, antara pihak pro dan kontra. Mereka yang pro terhadap LGBT menyatakan, bahwa negara dan masyarakat harus mengkampanyekan prinsip non diskriminasi antara lelaki, perempuan, trangender, pecinta lawan jenis (heteroseksual) maupun pecinta sejenis (homoseksual). Pendukung LGBT menggunakan pemenuhan hak asasi manusia sebagai dasar tuntutan mereka dengan menyatakan bahwa orientasi seksual adalah hak asasi manusia bagi mereka.

Sebaliknya, pihak-pihak yang kontra terhadap LGBT, menilai bahwa LGBT sebagai bentuk penyimpangan, dan tidak masuk dalam konsepsi HAM. Dalam hal ini, negara dan masyarakat harus berusaha semaksimal mungkin untuk melakukan upaya preventif terhadap gejala muncul dan berkembangnya LGBT yang akan membahayakan generasi masa depan Indonesia. Oleh sebab itulah, posisi stategis pemerintah dalam hal ini sangat diperlukan untuk menangani polemik LGBT secara langsung agar tak terjadi disintegrasi bangsa.

Situasi yang terjadi di Indonesia terkait fenomena LGBT tersebut, tentunya tidak dapat dilepaskan dari gejolak fenomena LGBT yang terjadi di tingkatan dunia internasional. Pada tahun 2011, Dewan Hak Asasi Manusia PBB mengeluarkan resolusi pertama tentang pengakuan atas hak-hak LGBT, yang diikuti dengan laporan dari Komisi Hak Asasi Manusia PBB yang mendokumentasikan pelanggaran hak-hak dari orang-orang LGBT, termasuk kejahatan kebencian, kriminalisasi homoseksualitas, dan diskriminasi. Menindaklanjuti laporan tersebut, Komisi Hak Asasi Manusia PBB mendesak semua negara untuk memberlakukan hukum yang melindungi hak-hak LGBT. Dasar aturan yang digunakan oleh PBB adalah dalam perspektif Universal Declaration of Human Rights (Deklarasi Universal Hak-Hak Asasi Manusia), Dewan Hak Asasi Manusia PBB mensyahkan resolusi persamaan hak yang menyatakan bahwa setiap manusia dilahirkan bebas dan sederajat dan setiap orang berhak untuk memperoleh hak dan kebebasannya tanpa diskriminasi apapun.

Resolusi tentang pengakuan atas hakhak LGBT adalah resolusi PBB yang pertama yang secara spesifik mengangkat isu pelanggaran HAM berdasarkan orientasi seksual dan identitas gender. Resolusi tentang 
pengakuan atas hak-hak LGBT inilah yang dijadikan sebagai landasan tuntutan bagi kaum LGBT dalam menuntut hak-hak mereka dengan mengatasnamakan hak asasi manusia. Namun demikian, tentunya berbicara mengenai hak asasi manusia, maka tidak akan terlepas dari hukum dan falsafah yang dianut suatu Negara. Bagi negara Indonesia, yang berlandaskan atas hukum dan Pancasila, maka negara akan menghargai hak-hak setiap warga negara dan penegakkan HAM pun akan disesuaikan dengan nilai-nilai dan falsafah yang dianut bangsa Indonesia.

\section{Pembahasan}

\subsection{Tinjauan Mengenai LGBT}

Negara Amerika sangat fokus terhadap isu hak asasi LGBT, karena menurut mereka dengan tidak adanya diskriminasi dan kriminalisasi terhadap orang-orang LGBT, maka kehidupan LGBT akan berjalan sama 'normalnya' dengan orang-orang heteroseksual. PBB telah bekerja dengan negara-negara anggota untuk menolak diskriminasi dan kriminalisasi berdasarkan homofobia dan transphobia bagi LGBT. Hal ini sebagai bentuk pengakuan hak asasi manusia bagi orang-orang LGBT dan hasilnya lebih dari 30 negara telah melegalkan homoseksualitas dalam 20 tahun terakhir. Untuk menghadapi resistensi dari LSM dan kelompok yang menentang atas ketentuan dari PBB tersebut, maka PBB melalui perwakilan dari negara-negara anggota memerintahkan untuk menjamin hak asasi manusia LGBT. Hari ini, di bawah pimpinan Sekretaris Jenderal Ban Ki-moon, tidak ada keraguan bagi PBB untuk membuat keputusan menuju inklusi global mengenai pengakuan hak asasi manusia LGBT.

Keberadaan LGBT di dunia sudah ada sejak lama, berawal dari waktu terawal fenomena tersebut ditemukan yaitu abad ke19an. Pada abad ke-19, American Psychiatric Assosiation (APA) masih menganggap homoseksualitas sebagai mental disorder. Seperti pada perkembangan diagnosis para pskiater di Amerika beserta risetnya, pada tahun 1952 diagnosis asli dan Statistik Manual of Mental Health (DSM) menetapkan bahwa homoksesual adalah gangguan kepribadian sosiopat.

Seiring berjalannya waktu, komunitas orang-orang LGBT mendapatkan diskriminasi yang berat dari masyarakat. Mulai dari dikeluarkan dari pekerjaan, dianggap sebagai orang gila, sebagai kriminal, dan isu-isu diskriminasi lainnya. Pada tahun 1951, Donald Webster Cory menerbitkan The Homoseksual di Amerika (Cory, 1951), yang menyatakan bahwa laki-laki gay dan lesbian adalah kelompok minoritas yang sah. Hingga tahun 1950-1970an komunitas pendukung LGBT memunculkan gerakan meminta ditiadakannya diskriminasi terhadap komunitas LGBT.

Sejalan dengan hal tersebut, pada tahun 1968 DSM menghapuskan homoseksual dari daftar sosiopat. Pada akhirnya karena terdapat 
efek politik di dalam tuntutan hak komunitas LGBT, tepatnya tahun 1973, American Psychiatric Association menghapus homoseksualitas dari DSM dan menjelaskan bahwa homoseksualitas tidak lagi dianggap sebagai penyakit mental. Homoseksual dianggap sebagai perilaku biasa, namun menjadi masalah ketika orang homoseks tersebut mengalami kerugian atau ketidaknyamanan hingga harus diterapi.

Sejarah perkembangan pandangan masyarakat terhadap LGBT berawal dari perspektif Socarides yang menceritakan bagaimana sejarahnya LGBT di Amerika. Charles W Socarides MD adalah seorang Psikiater dan Psikoanalisis di Amerika yang meneliti tentang kaum LGBT. Socarides beranggapan bahwa gay itu bukan merupakan bawaan sejak lahir, dengan kata lain bukan merupakan genetik seperti yang kaum gay klaim pada masa itu. Menurut Socarides mereka berubah menjadi gay karena wawasan dan berpikir secara sadar.

Awalnya pada tahun 1952, Diagnostic and Statistical Manual (DSM) menyatakan kaum homoseksual sebagai "gangguan kepribadian sosiopat". Kemudian pada tahun 1968 kaum homoseksual dinyatakan sebagai “penyimpangan seksual”. Setelah itu, pada tahun 1973 homoseksual dinyatakan sebagai “penyakit mental”. Namun setelah tahun 1973 melalui American Psychiatric Association, kaum homoseksual dinyatakan "bukan penyakit mental".
Fakanya, faktor penyebab mengapa American Psychiatric Association menghapus pernyataannya pada kaum homoseksual sebagai "penyakit mental" adalah banyaknya aktivis gay yang memprotes konvensi American Psychiatric Association di San Francisco. Kemudian American Psychiatric Association semakin tidak nyaman dengan sikap para kaum homoseksual. Lalu American Psychiatric Association memutuskan homoseksual adalah normal (bukan penyakit kejiwaan) dengan hasil voting anggotanya 130 dengan 2 abstain. Sekitar 55\% dari anggota American Psychiatric Association yang suka dengan keputusan tersebut. Jadi, American Psychiatric Association menghapus homoseksual dari daftar penyakit mental tidak dipicu oleh beberapa terobosan ilmiah melainkan karena keributan yang terjadi oleh kaum homoseksual pada masa itu sehingga membuat suara mereka didengar masyarakat. American Psychiatric Association khawatir hal ini menimbulkan peningkatan perhatian masyarakat terhadap sifat palsu dari seluruh taksonomi mereka. Kemudian pada saat itu terjadi pula ancaman-ancaman yang berpotensi menyebabkan tindak kekerasan sehingga American Psychiatric Association menghapus pernyataannya mengenai homoseksual.

Charles W. Socarides MD beranggapan bahwa gay itu bukan bawaan sejak lahir atau genetik. Menurutnya mereka berubah karena wawasan dan berpikir secara sadar. Hal ini sejalan dengan apa yang 
dipaparkan sebelumnya mengenai beberapa faktor yang dapat mempengaruhi seseorang dapat berubah menjadi LGBT. Faktor biologis tidak begitu dominan dalam hal ini, karena nampaknya lebih ke arah psikososial atau masa perkembangan yang dialami oleh seorang anak sejak ia lahir. Namun ini bukan berarti seorang anak lahir dengan kelainan genetik dan membuatnya menjadi memiliki orientasi seksual sesama jenis seperti yang di klaim kebanyakan kaum LGBT saat ini. Terbukti dengan adanya faktor lingkungan yang juga dapat berpengaruh terhadap seseorang untuk menjadi seorang LGBT. Seperti yang Socarides katakan bahwa LGBT telah berkembang menjadi gaya hidup alternatif bagi masyarakat. Artinya seseorang dapat menjadi LGBT dengan adanya informasi dan wawasan yang membuat pola pikir seseorang berubah dan secara tidak langsung dapat merubah orientasi seksualnya juga. Dengan demikian, LGBT dapat ditangani dengan terapi untuk merubah pola pikir mereka.

Socarides pun dulu sebagai pencetus sebuah lembaga psikiater yang menangani masalah LGBT pada masanya. Pada masa itu Socarides menangani kaum LGBT yang merasa tidak nyaman dengan kondisinya dan ingin berubah. Socarides melakukan terapi penetralan dengan cara meredefinisi radikal mengenai homoseksual itu sendiri. Banyak dari klien Socarides yang sembuh dan menjadi heteroseksual. Namun LGBT masa kini sudah tidak lagi menganggap dirinya bermasalah karena sudah sejak lama adanya pencetusan anggapan bahwa LGBT bukan lagi merupakan “penyakit mental” oleh American Psychiatric Association. Padahal di sisi lain American Psychiatric Association mengubah ketentuan mengenai fenomena LGBT tersebut bukan karena terbukti sepenuhnya secara ilmiah melainkan karena adanya intimidasi dari kaum LGBT pada masa itu sehingga membuat American Psychiatric Association merasa terganggu dengan berbagai terror yang dilakukan kaum LGBT pada lembaga tersebut.

\subsection{Tinjauan Mengenai Hak Asasi Manusia (HAM)}

Hak asasi manusia dalam Bahasa Prancis disebut "Droit L'Homme", yang artinya hak-hak manusia dan dalam Bahasa Inggris disebut "Human Rights". Seiring dengan perkembangan ajaran Negara Hukum, di mana manusia atau warga negara mempunyai hak-hak utama dan mendasar yang wajib dilindungi oleh Pemerintah, maka muncul istilah "Basic Rights" atau "Fundamental Rights". Bila diterjemahkan ke dalam Bahasa Indonesia adalah merupakan hak-hak dasar manusia atau lebih dikenal dengan istilah "Hak asasi manusia". Sedangkan Meriam Budiardjo, dalam bukunya Dasar-dasar Ilmu Politik menyatakan bahwa: "Hak asasi manusia adalah hak yang dimiliki manusia yang telah diperoleh dan dibawanya bersamaan dengan kelahirannya di dalam kehidupan masyarakat. Dianggap bahwa 
beberapa hak itu dimilikinya tanpa perbedaan atas dasar bangsa, ras, agama, kelamin dan arena itu bersifat universal. Dasar dari semua hak asasi ialah bahwa manusia memperoleh kesempatan berkembang sesuai dengan harkat dan cita-citanya.

Kemudian Leach Levin seorang aktivis hak asasi manusia Perserikatan BangsaBangsa mengemukakan bahwa konsep hak asasi manusia ada dua pengertian dasar, yaitu: Pertama, ialah bahwa hak asasi manusia tidak bisa dipisahkan dan dicabut adalah hak manusia karena ia seorang manusia. Hak adalah hak-hak moral yang berasal dari kemanusiaan setiap insan dan hak-hak itu bertujuan untuk menjamin martabat setiap manusia (natural rights). Kedua, hak asasi manusia adalah hak-hak menurut hukum, yang dibuat melalui proses pembentukan hukum dari masyarakat itu sendiri, baik secara nasional maupun secara internasional. Dasar dari hak-hak ini adalah persetujuan dari yang diperintah, yaitu persetujuan dari yang diperintah, yaitu persetujuan dari para warga negara, yang tunduk kepada hak-hak itu dan tidak hanya tata tertib alamiah yang merupakan dasar dari arti yang pertama.

Terdapat berbagai batasan mengenai HAM, Hendarmin Ranadirekasa (dalam Muladi 2005) memberikan definisi tentang HAM pada hakekatnya adalah seperangkat ketentuan atau aturan untuk melindungi wargna negara dari kemungkinan penindasan, pemasungan dana tau pembatasan ruang gerak warga negara oleh negara, artinya ada pembatasan-pembatasan tertentu yang diberlakukan pada negara agar hak warga negara yang paling hakiki terlindungi dari kesewenang-wenangan kekuasaan. Sedangkan Mahfu MD (dalam Muladi 2005) mengartikan HAM sebagai hak yang melekat pada martabat manusia sebagai makhluk ciptaan Tuhan, dan hak tersebut dibawa manusia sejak lahir di ke muka bumi sehingga hak tersebut bersifat fitri (kodrati), bukan merupakan pemberian dari manusia atau negara. Sehingga dari dua pengertian diatas bisa disimpulkan bahwa HAM adalah hak dasar yang melekat pada setiap individu sejak dilahirkan kemuka bumi dan bukan merupakan pemberian manusia atau negara yang wajib dilindungi oleh negara.

Berdasarkan definisi diatas terliht bagaimana posisi HAM dengan hukum yang dibuat oleh negara. Keberadaan HAM mendahului hukum dengan kata lain bahwa hak asasi manusia adalah hak dasar yang melekat pada diri manusia sepanjang hidupnya sebagai anugrah Tuhan, bersifat universal dan harus dilindungi secara hukum atau HAM diformalkan kedalam seperangkat aturan hukum yang ada. Dari posisi tersebut, hukum menjadi condition sine qua non dalam penegakan HAM, lengkapnya instrumen hukum tentang HAM menjadi salah satu sumber human right law yang menunggu langkah politik pemimpin dunia dan pemimpin negara untuk menegakkannya. 
Isi dari pada hak asasi manusia hanya dapat ditelusuri lewat penelusuran aturan hukum dan moral yang berlaku dalam masyarakat. John Locke (1632-1704) yang dikenal sebagai bapak hak asasi manusia, dalam bukunya yang berjudul "Two Treatises On Civil Government", menyatakan tujuan negara adalah untuk melindungi hak asasi mansuia warga negaranya. Manusia sebelum hidup bernegara atau dalam keadaan alamiah (status naturalis) telah hidup dengan damai dengan haknya masing-masing, yaitu hak untuk hidup, hak atas kemerdekaan dan hak atas penghormatan terhadap harta miliknya, yang semua itu merupakan propertinya.

Dalam HAM terdapat dua pinsip penting yang melatarbelakangi konsep HAM itu sendiri yakni prinsip kebebasan dan persamaan, dimana dua hal tersebut merupakan dasar dari adanya sebuah keadilan. John Rawis, berpendapat bahwa terdapat tiga hal yang merupakan solusi bagi problem utama keadilan yaitu:

1. Prinsip kebebasan yang sebesarbesarnya bagi setiap orang (principle of greatest equel liberty). Prinsip ini mencakup kebebasan untuk berperan serta dalam kehidupan politik, kebebasan berbicara, kebebasan pers, kebebadan memeluk agama, kebebasan menjadi diri sendiri, kebebasan dari penangkapan dan penahanan yang sewenang-wenang, dan hak untuk mempertahankan milik pribadi.
2. Prinsip perbedaan (the difference principle). Inti dari prinsip ini adalah perbedaan sosial ekonomi harus diatur agar memberikan kemanfaatan yang besar bagi mereka yang kurang diuntungkan.

3. Prinsip persamaan yang adil atas kesempatan (the principle of fair equality of opportunity). Inti dari prinsip ini adalah bahwa ketidaksamaan sosial ekonomi harus diatur sedemikian rupa sehingga membuka jabatan dan kedudukan sosial bagis semua orang dibawah kondisi persamaan kesempatan.

Berdasarkan prinsip diatas dapat dilihat bahwa ketiga prinsip tersebut merupakan halhal pokok yang ada dalam HAM, dimana HAM tidak melihat kedudukan ekonomi, sosial dan budaya seseorang, serta tidak melihat bagaimana kedudukannya sabagai orang sipil maupun kedudukannya dalam hal politik, semua orang memilki kebebasan dan juga mempunyai kedudukan yang sama.

Hak asasi manusia di Indonesia bersumber dan bermuara pada Pancasila, yang artinya hak asasi manusia mendapat jaminan kuat dari falsafah bangsa, yakni Pancasila. Bermuara pada Pancasila dimaksudkan bahwa pelakasanaan hak asasi manusia tersebut harus memperhatikan garis-garis yang telah ditentukan dalam ketentuan falsafah Pancasila. Bagi bangsa Indonesia, melaksanakan hak asasi manusia bukan berarti melaksanakan 
dengan sebebas-bebasnya, melainkan harus memperhatikan ketentuan-ketentuan yang terkandung dalam pandangan hidup bangsa Indonesia, yaitu Pancasila. Hal ini disebabkan pada dasarnya memang tidak ada hak yang dapat dilaksanakan secara mutlak tanpa memperhatikan hak-hak orang lain. Setiap hak yang dimiliki oleh seseorang akan dibatasi oleh hak orang lain. Jika dalam melaksanankan hak, kita tidak memperhatikan hak orang lain, maka yang terjadi adalah benturan hak atau benturan kepentingan dalam hidup bermasyarakat, berbangsa dan bernegara.

Negara Republik Indonesia mengakui dan menjunjung tinggi hak asasi manusia dan kebebasan dasar manusia sebagai hak yang secara kodrati melekat dan tidak terpisah dari manusia yang harus dilindungi, dihormati, dan ditegakkan demi peningkatan martabat kemanusiaan, kesejahteraan, kebahagiaan, dan kecerdasan serta keadilan.

Prinsip-prinsip tentang HAM tersebut dapat dilihat dalam berbagai instrumen, diantaranya:

1. Undang-Undang Dasar 1945, Yang tertuang dalam Pasal 28I, Pasal 28J UUD NRI Tahun 1945.

2. Undang-Undang Nomor 39 Tahun 1999 tentang Hak Asasi Manusia, dalam Bab I tentang Ketentuan Umum dan Bab II tentang Asas-asas dasar.

Dimana dalam dua instrumen diatas dapat disimpulkan bahwa: HAM adalah seperangkat hak yang melekat pada hakikat dan keberadaan manusia sebagai makhluk Tuhan YME, dan merupakan anugrah Tuhan yang wajib dihormati, dijunjung tinggi dan dilindungi tidak saja oleh negara namun juga oleh setiap orang, dan manusia tidak hanya memiliki HAM namun secara jelas disebutkan bahwa manusia juga memiliki kewajiban dasar dimana ketika kewajiban itu tidak dilaksanakan maka tidak akan dimungkinkan adanya pelaksanaan dan tegaknya HAM, hal itu sebagai penyeimbang keberlakuan HAM.

LGBT adalah sebuah penyimpangan dari kodrat dan fitrah manusia. Manusia sejatinya diciptakan dalam dua jenis untuk berpasangan, yaitu pria dan wanita. Konsepsi itu jelas dianut oleh UU No. 1 Tahun 1974 tentang Perkawinan. Perkawinan menurut Pasal 1 undang-undang tersebut, hanya antara pria dan wanita. Dengan begitu, perkawinan sejenis bertentangan dengan hukum Indonesia.

Di Indonesia secara garis besar disimpulkan, hak-hak asasi manusia itu dapat dibeda-bedakan menjadi sebagai berikut:

1. Hak pribadi (personal rights) yang meliputi kebebasan menyatakan pendapat, kebebasan memeluk agama, dan kebebasan bergerak.

2. Hak ekonomi (property rights) yang meliputi hak untuk memiliki sesuatu, hak untuk membeli dan menjual serta memanfaatkannya.

3. Hak politik (political rights) yaitu hak untuk ikut serta dalam pemerintahan, hak pilih (dipilih dan memilih dalam 
pemilu) dan hak untuk mendirikan partai politik.

4. Hak untuk mendapatkan perlakuan yang sama dalam hukum dan pemerintahan.

5. Hak sosial dan kebudayaan (social and culture rights). Misalnya hak untuk memilh pendidikan dan hak untuk mengembangkan kebudayaan.

6. Hak asasi untuk mendapatkan perlakuan tata cara peradilan dan perlindungan (procedural rights). Misalnya peraturan dalam hal penahanan, penangkapan, penggeledahan, dan peradilan.

Bagi bangsa Indonesia, dengan instrumen hukumnya, harus menjamin perlindungan dan pemenuhan HAM. Hukum tak boleh lepas dari nilai-nilai keberadaban dan senantiasa bersesuaian dengan akal sehat dan fitrah manusia. Hukum ada untuk melindungi harkat dan martabat kemanusiaan.

\section{Simpulan}

Pergeseran pandangan masyarakat dunia terhadap komunitas LGBT sangat dipengaruhi oleh pernyataan yang dikeluarkan oleh American Psychiatric Association sebagai lembaga yang dipandang kompeten untuk memberikan penilaian terhadap keberadaan komunitas LGBT. Pergeseran pandangan American Psychiatric Association tampak sebagai berikut: pada tahun 1952 kaum homoseksual dinyatakan sebagai orang dengan "gangguan kepribadian sosiopat" sehingga dimasukkan ke dalam Diagnostic and Statistical Manual (DSM). Kemudian pada tahun 1968 kaum homoseksual dinyatakan sebagai "penyimpangan seksual". Setelah itu, pada tahun 1973 homoseksual dinyatakan sebagai "penyakit mental". Namun karena adanya ancaman-ancaman yang berpotensi menyebabkan tindak kekerasan, setelah tahun 1973 kaum homoseksual dinyatakan "bukan penyakit mental".

Tuntutan LGBT terhadap pemenuhan hak asasi manusia, tentunya harus disesuaikan dengan nilai-nilai dan aturan hukum yang berlaku di Indonesia. Di sisi lain sejalan dengan pandangan Charles W. Socarides MD bahwa gay bukan bawaan sejak lahir (genetik). Seseorang menjadi gay karena wawasan dan pikiran secara sadar, dengan kata lain menjadi gay karena dipelajari secara sadar. Pengaruh faktor biologis tidak begitu dominan, karena nampaknya faktor psikososial atau masa perkembangan yang dialami oleh seorang anak sejak ia lahir akan berpengaruh lebih besar terhadap keberadaan gay.

\section{Perkembangan HAM secara} kontemporer telah dibentuk oleh pemikiran Barat dan dalam hal ini, banyak konsep yang sering digunakan dalam perdebatan politik, seperti: demokrasi, keadilan, kebebasan, kesetaraan dan martabat manusia. Dengan demikian, sebagai upaya untuk menghentikan penggunaan kata-kata tersebut agar tidak secara otomatis diasosiasikan dengan konsep 
HAM, maka tugas kita sebagai orang Indonesia yang memiliki tata nilai dan tata kelakuan yang berbeda dengan bangsa Barat adalah dengan melonggarkan konsep-konsep HAM dari belenggu modernitas Barat dan merekonstruksi konsep-konsep HAM berdasarkan pemikiran dan nilai-nilai bangsa Indonesia.

Bila kita menilik istilah HAM yang menjunjung ide-ide dan nilai-nilai kemanusiaan serta berlaku secara universal, tampaknya dalam hal ini HAM beresonansi lintas budaya dan tradisi, sehingga HAM merupakan seruan penting bagi mereka yang mencari keadilan dan perdamaian di dunia secara berkelanjutan. Terhadap konsep HAM yang demikian, muncul beberapa kritik pemikiran.

Kritik pertama, mengenai bias budaya. Sebagaimana kita ketahui, bahwa setiap manusia yang menempati tempat tertentu pada waktu tertentu memiliki budayanya masingmasing dan adakalanya satu budaya dengan budaya yang lainnya tidak sejalan dan bahkan saling bertentangan. Selain kritik terhadap bias budaya, dua kritik lainnya secara umum terkait dengan perspektif HAM itu sendiri. Kritik kedua, bahwa klaim HAM dinilai sembrono atau egois: orang akan mengklaim sesuatu sebagai "hak asasi manusia"-nya, padahal sebenarnya mereka hanya mengekspresikan egois sederhana "ingin". Kritik ketiga, bahwa klaim hak asasi manusia seseorang dapat bertentangan dengan klaim atas hak asasi manusia orang yang lainnya.

\section{Daftar Pustaka}

Cory, D. W. 1951. The homosexual in America: A subjective approach. New York: Greenberg.

Drescher, Jack. Hellman, Ronald. 2004. Handbook of LGBT Issues in Community Mental Health. New York: The Haworth Medical Press

Friedman, Howard S. 2015. Encyclopedia of Mental Health. Academic Press.

Ife, Jim. 2008. Human Rights And Social Work. New York: Cambridge University Press.

Muladi. 2005. Hak Asasi Manusia: Hakekat, Konsep dan Implikasinya Dalam Perspektif Hukum dan Masyarakat, Bandung: Refika Aditama.

Efendi, Masyur. \& Sukmana, Taufani E. 2007. HAM: Dalam Dimensi / Dinamika Yuridis, Sosial, Politik, Bogor: Ghalia Indonesia.

Meriam Budiardjo. 1980. Dasar-Dasar Ilmu Politik. Jakarta: PT. Gramedia.

Naming, Ramblon. 1982. Gatra Ilmu Negara. Yogyakarta: Liberty.

Subawa, I Made. 2008. Hak Asasi Manusia Bidang Ekonomi Sosial dan Budaya Menurut Perubahan UUD 1945. Jurnal Kertha Patrika vol. 33 no. 1, Januari 2008. 